\title{
CORRESPONDENCE
}

\author{
THE USK MONCHIQUITE-A "PIPE INTRUSION"
}

SIR,-The discovery of the Usk monchiquite is reputed to be due to a former Cardiff student who noted a very black rock being used as a roadstone on a private drive. He took specimens to Professor W. S. Boulton, then Professor at Cardiff, who gave an account of the occurrence (Quart. Journ. Geol. Soc., 1911, Ixvii, 460).

The present author made a number of visits with student parties during the period 1920-1938. There was then only a small exposure at the side of a private drive, with the rocks almost concealed by vegetation.

When class excursions were resumed after the second war, it was found that a quarry, about $200 \mathrm{ft}$. long, had been opened on the monchiquite outcrop, presumably to obtain material for camp roadways, other hard stone being scarce in that part of the Old Red Sandstone outcrop.

The higher side of the quarry wall then afforded a fine vertical section of the monchiquite intrusion, but the floor of the quarry was concealed by a great mass of large blocks of unweathered monchiquite liberated by blasting.

The quarry face consisted partly of unweathered and partly of weathered material. The junctions of weathered and unweathered material were exceedingly irregular, and in places the original intrusive rock had weathered to a reddish-brown soil, with included blocks showing all stages from the fresh black rock to the brown soil.

The new and larger exposures sufficed to show that the occurrence was a pipe-intrusion exactly similar to occurrences of kimberlite pipes in the Kimberley area of South Africa.

The similarity to the South African pipes is, of course, no guarantee that the Monmouthshire intrusion carries any material of economic importance. There are plenty of "pipes" in South Africa which fail to yield any minerals of commercial importance.

Along a large part of the exposure in the quarry wall the intrusive rock extended right up to the surface. But on one side of the excavation the igneous rock was overlain by a deposit of well-rounded pebbles which must have come from a considerable distance.

A more recent visit, 1954, showed considerable changes in the appearance of the ground in the vicinity. The former extensive woods had all been cut and turned into agricultural ground, so that it would now be difficult to recognize the locality from Professor Boulton's original description, though the newer pre-1948 quarry is still visible on a cleared hillside.

\footnotetext{
"TAN-Y-RHIW,"

RHIWBINA HILL, NR. CARDIFF.
}

A. Hubert Cox.

19th October, 1954.

\section{THE GREAT GLEN FAULT, CO. DONEGAL}

SIR,-In a recent issue of the Magazine (Vol. xci, p. 338), J. B. Auden poses the question of the extension of the Great Glen Fault into Co. Donegal. In the process of surveying a large tract of the western and northern parts of that County we have already accumulated considerable evidence of the presence of a major S.W. trending fault.

Such a dislocation can be traced from the northern tip of Inishowen, along the northern side of the Knockalla Mountains, through the Leannan valley and through the localities of Drumbologe Bridge, Swilly Bridge, Cummirk Bridge, and thence presumably by Lough Ea and Sir Albert's Bridge. In Inishowen it constitutes the smash zone of W. J. McCallien (1935, Proc. Roy. Irish Acad., xlii, p. 407), north of Knockella it forms the faulted boundary of an outlier of presumed Old Red Sandstone age (H. E. Wilson, 1953, Proc. Roy. Irish Acad., Iv, Sec. B, No. 13, p. 294), near Milford two very 